\title{
Financial Reporting Practices and Sustainability of Micro Small and Medium Enterprises (MSMEs) in Akwa Ibom State
}

Etim Osim Etim ${ }^{1 *}$, Emmanuel E. Daferighe ${ }^{2}$, Mmayen Ofonime UKPONG $^{3}$

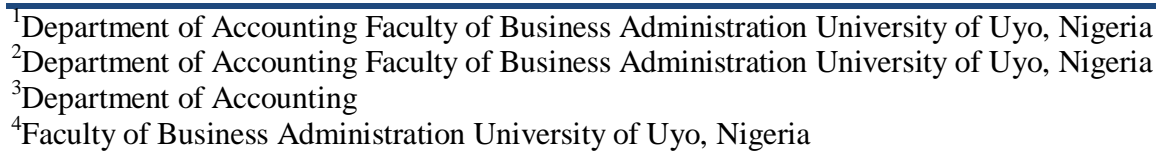

Article History
Received: 05.12 .2020
Accepted: 17.12 .2020
Published: 28.12 .2020
Journal homepage:
https://www.easpublisher.com
Quick Response Code
development has been attributed to contributions of Micro, Small, and Medium Scale Enterprises (MSMEs), unfortunately in Nigeria; these entities have not been performing optimally and are characterized by a high mortality rate. While many reasons have been theoretically and empirically advanced for these, such as poor management skills, weak financial base and poor financial management practice, hostile operating environment, among others, this study was conceived to empirically examine the linkage between financial reporting practices and sustainability of the MSMEs sub-sector; as it is believed these practices are among causes of mortality. To achieve the main objective, a structured questionnaire was designed to gather data from 185 operators of MSMEs drawn using a multi-stage sampling technique involving stratified sampling, cluster sampling, random sampling, and purposive sampling. The primary data collected were analyzed using descriptive statistics (mean analysis), simple and multiple regressions to test the individual and joint effects of the independent variables (financial accounting practices, auditing practices, and cost/management accounting practice) on the dependent variable (sustainability of MSMEs). The analysis was well carried out at a 5\% level of significance. The coefficients of the simple regression were financial accounting practice $(\beta=.029$, std. error $=.005, \mathrm{t}=5.892$, $\mathrm{p}$-value $=.000)$; auditing practices $(\beta=$ 0.002 , std. error $=0.009, \mathrm{t}=-.400, \mathrm{p}$-value $=0.626)$, cost $/$ management accounting practice $(\beta=-.002$, std. error $=0.009, \mathrm{t}=0.178$, $\mathrm{p}$-value $=0.859)$, showing that only financial accounting practices were statistically significant. ointly, the adjusted $\mathrm{R}^{2}=$ $14.9 \%, \mathrm{~F}$-cal $=11.659$ and $\mathrm{p}$-value $=0.000<0.05$ implying that the variables were jointly statistically significant accounting for $14.9 \%$ variation in sustainability of MSMEs. It was, therefore, recommended that more attention be paid to improving knowledge of MSMEs operators on the adoption and usage of financial accounting practices, installation of internal control/audit units and engagement of external auditors as well as the adoption of contemporary cost and management accounting practices to enhance their sustainability.

Keywords: MSMEs, Sustainability, Financial Reporting Practices.

Copyright $\odot 2020$ The Author(s): This is an open-access article distributed under the terms of the Creative Commons Attribution 4.0 International License (CC BY-NC 4.0) which permits unrestricted use, distribution, and reproduction in any medium for non-commercial use provided the original author and source are credited.

\section{INTRODUCTION}

There exist an increasing and growing acceptance of the relevance of micro and small businesses as a veritable tool for the economic sustainability of many nations [1] Zotorvie, [2] described MSMEs as the basis of growth for both advanced and non-advanced nations. This contribution encompasses, job creation, capacity utilization, technological advancement, and human resource development. For instance, MSMEs, employ about 50\% of the United States of America (USA) workforce while in the enlarged European Union nations, about 23 million MSMEs create approximately 75 million jobs which represent about $95 \%$ of all enterprises [3, 4], create about $85 \%$ of employment in the manufacturing sector in Nigeria and Ghana while it is believed that small businesses contribute about $85 \%$ and $70 \%$ to these countries GDP respectively [5].

The situation is not much different in Nigeria and other African countries as MSMEs contribute to the general wellbeing of the nation. Thus, this demonstrates that MSMEs are like pivots upon which the economic growth and development of nations revolve. However, there have been concerns regarding the sustainability of these MSMEs giving the competitive and dynamic operating environment. This may be due to the failure of many MSMEs in the utilization of available 
resources to actualize their growth potentials. It has also been attributed to improper and inadequate financial reporting practices which hinder timely and profitable decision making $[6,2]$. However, it is documented that most MSMEs owners have poor record-keeping behavior. Supporting that view, Howard [7] and Madurapperuma, Thilakerathne, and Manawadu [8] argued that non-adoption of financial reporting techniques such as external auditing, taxation planning; non-application of accounting practices such as cost and management accounting principles among others have led to major problems. Larson and Cute [9] added that poor internal accounting practices of some MSMEs eventually lead to poor planning, excessive expenses, lack of controls, and low collection of trade receivables, and poor record-keeping which ought to be utilized for effective decision making.

Regardless of the lofty potentials and various efforts by governments at different levels as well as other development agencies such as United Nations International Development Organization (UNIDO) to create a vibrant MSMEs sub-sector in Nigeria generally and in Akwa Ibom State, in particular, poor performance and the high mortality rate has continued to be the bane of the subsector in the country [10]. Turyahebwa, Sunday, and Sekajuge [11] posit that poor business performance among these categories of entities has derailed the macro-economic objective of developing nations, where MSMEs constitute a greater proportion of all business activities in the economy. About $60 \%$ of MSMEs in developing countries fail before their fifth anniversary [12].

Financial accounting and reporting practices are a vital part of any company's business, as it does not only facilitate companies to keep track of their financial transaction but are equally a legal obligation in many countries particularly for taxation purposes. Thus, the inability of owners of MSMEs to keep proper accounting information on these business transactions affects both their performance and survival in the longrun. Therefore, effective financial reporting practices that are internally developed and installed by organizations help in detailed information about the strengths and weaknesses of a business entity.

Undoubtedly, the continuity or closure of any business hugely depends on keeping accurate, timely, and reliable information that could help in assessing the true position of an organization [13]. This furthered the belief that there is a correlation between financial reporting practices and the sustainability of Micro, Small and Medium Scale (MSMEs) enterprises. However, the extent of this link has to be empirically established with data gathered from operators of these businesses within Akwa Ibom State. Thus, the survival and long-run sustainability of any entity may be linked to having a barometer or yardstick for measuring or gauging what is being done in the organization to determine the functionality of the entity. This study is in furtherance of the need to empirically find out how financial reporting practices have sustained MSME in Akwa Ibom State.

\section{Statement of the problem}

The Nigeria economy is perturbed with the increasing need to curb the high rate of unemployment, low income, insurgency, and youth restiveness which has become common issues across the country. Government at both the federal and states levels, over the years, has adopted several proactive measures to tackle these problems. Since the year 2000, Government has invested heavily in establishing and promoting the MSME sub-sector with the belief that the sub-sector would aid stimulate economic growth and development as well as help in solving the problem of unemployment and poverty in the economy.

Among the programs designed to assist improve the fortunes of MSMEs in the country are the Small and Medium Enterprise Development Agency of Nigeria (SMEDAN) in 2003; the National Economic Empowerment and Development Strategy (NEEDS) in 2004, Central Bank of Nigeria (CBN) refinancing and restructuring scheme in 2007 which disburse \$235. Billion to more than 550 MSMEs in the country between 2007 and 2013 [14]; National Poverty Eradication Programme (NAPEP) in 2011; the Akwa Ibom State Anchor Borrowers Scheme in 2016, among many others.

Unfortunately, despite all these programs, most of the MSMEs hardly survive beyond five (5) years of commencing operations [12, 4]. This high mortality rate is documented to be associated with MSMEs' failure to produce proper financial reports for better assessment [15]. Eloho [16] contends that the misuse, untimely, and inaccuracy of accounting information, inaccurate assessment of the financial situation of MSMEs leads to poor financial decisions which affect their sustainability and going concern status.

Although there are many assertions in the literature about the relevance and contributions of financial reporting practices to the sustainability of MSMEs, however, such claims are yet to be adequately demonstrated empirically in Akwa Ibom State, as found by the researcher. Specifically, there is a lack of studies on the influences of various financial reporting constructs such as financial accounting, auditing, taxation, and cost and management accounting practices on the sustainability of MSMEs in the state. This calls for the need to ascertain the link between the sustainability of MSMEs in Akwa Ibom State and financial reporting practices. 


\section{OBJECTIVES OF THE STUDY}

The primary objective of this study is to ascertain the linkage between financial reporting practices and the sustainability of MSMEs in Akwa Ibom State.

Other specific objectives are:

i. $\quad$ To find out the various commonly adopted financial reporting practices by MSMEs in Akwa Ibom State.

ii. To ascertain the extent to which financial accounting practices can sustain MSMEs in Akwa Ibom State.

iii. To evaluate the effect of auditing practices on the sustainability of MSMEs in Akwa Ibom State.

iv. To appraise the influence of cost and management accounting practices on the sustainability of MSMEs in Akwa Ibom State.

v. To find out the joint correlation between financial accounting, auditing, and cost/management accounting practices on the sustainability of MSMEs in Akwa Ibom State.

\section{Research Questions} for this study:

The following research questions were raised

i. What are the commonly adopted financial reporting practices by MSMEs operators in Akwa Ibom State?

ii. What effect does financial accounting practice have on the sustainability of MSMEs in Akwa Ibom State?

iii. Do auditing practices affect the sustainability of MSMEs in Akwa Ibom State?

iv. What influence does cost/management accounting practices have on the sustainability of MSMEs in Akwa Ibom State?

v. Do financial accounting, auditing, and cost/management accounting practices have any joint effect on the sustainability of MSMEs in Akwa Ibom State?

\section{Research Hypotheses}

The following hypotheses were formulated for this study:

$\mathrm{Ho}_{1} \quad$ Financial accounting practices do not affect the sustainability of MSMEs in Akwa Ibom State.

$\mathrm{Ho}_{2} \quad$ Auditing practices has no significant relationship with the sustainability of MSMEs in Akwa Ibom State

$\mathrm{Ho}_{3}$ Cost/management accounting practices have no significant relationship with the sustainability of MSMEs in Akwa Ibom State.

$\mathrm{Ho}_{4}$ The joint effect of financial accounting, auditing, and cost/management practices does not significantly affect the sustainability of MSMEs.

\section{Significance of the study}

After this study, the findings could be of immense benefit to many stakeholders involved in the MSMEs value chain development as it is expected to highlight the link between financial reporting practices and the sustainability of MSMEs.

Firstly, the owner-managers of MSMEs would appreciate the need to adopt basic financial reporting practices to sustain their businesses and assessment of operational performance with ease from financial records maintained.

Secondly, the findings would provide useful guides to the design and implementation of policies that would revitalize the sub-sector and assist it to grow thereby averting incessant bankruptcy and failures of businesses in the sub-sector.

Thirdly, it is also envisaged that this study could be an important source of reference material for future researchers and others in academia, who may wish to expand their knowledge of related issues affecting MSMEs. Thus, it will form part of the literature for those in academia.

Finally, management and financial consultants, as well as agencies of government, will find the findings of this study quite useful in carrying out their assigned obligations, particularly in their consulting functions and tax assessment obligations in the area of personal income tax.

\section{REVIEW OF RELATED LITERATURE}

This section of the study comprises of three main sections: conceptual framework, theoretical framework, and empirical review.

\section{CONCEPTUAL FRAMEWORK}

The conceptual review is carried out to review the key concepts or variables of the study under different sub-headings as they relate to micro, small and medium enterprises (MSMEs) financial reporting practices and sustainability of MSMEs.

\section{Concept of micro, small and medium enterprises (MSMEs)}

Extant accounting literature is of the view that there is no generally accepted definition of micro, small and medium enterprise (MSMEs) across all academic disciplines and cultures [17, 18]. Rather, any definition used in a given study depends on the field of the writer as well as the objectives which the study intends to achieve. 
In practice and theory, many terms are used to describe MSME such as "small and medium enterprise" and "small and medium-sized enterprise", cottage industries", and so on. They are all somewhat different in meaning but it is not the focus of this study to examine the distinguishing differences among the terms, as they are being used interchangeably, as though having the same meaning. Although several definitions exist for MSME two criteria are used in this study according to Black [12], qualitative and quantitative bases of classification.

\section{Qualitative definition of MSMEs}

MSMEs definitions are defined here based on qualitative features. These definitions attempt to capture the fundamental nature of MSMEs by identifying certain features that are more often associated with small businesses than large ones. These include ownership structure; the degree of control; the degree of participation and decision making, and in the day-today operations of the business activities and the extent of employees' involvement [20,21].

In the United States of America (USA), the Committee of Economic Development (CED) in 1947 defined MSMEs based on the following four cardinal features:

1 Management of the business must be different from the owner(s).

2 Capital used for the business must be owned and supplied by an individual or group of individuals.

3 The business must be situated in a given community, and

4 Must be structurally small when compared with other businesses [22].

In the United Kingdom (UK), the Bolton committee 1971 further defined MSMEs as having the following features in mind: First, it should be a business entity that has a relatively small market share and has no economic power to influence both the quantity and price of goods produced. Second, the business must be managed by the owner(s) and not through a third party. Third, the business must be highly independent and free from third-party involvement in certain areas, particularly, decision making.

In Australia, the Wiltshire committee of inquiry in 1973 gave its definitional framework. Wiltshire [23] defines an MSME as a business entity that is made up of two or three persons that make fundamental decisions regarding the business and do not need external help on specific functional areas for the successful operation of the business. This viewpoint, however, is not generally referenced in Australia as each state government has its operational definition $[24,25]$.

In the case of Nigeria, various authors and institutions used different qualitative definitions of
MSMEs. For instance, institutions such as the Central Bank of Nigeria $(\mathrm{CBN})$, the Centre for Industrial Research and Development (CIRD), and the National Council on Industry (NCI) have different views as to what MSMEs entails. However, the following features that are typical of MSMEs were outlined by Ojo [26]:

- It must have easy entry and easy exit;

- It must predominantly make use of indigenous resources such as finance and materials;

- It is usually a family-owned business;

- The scale of operation is often small;

- Sourcing of labor is often family-based;

- Skills required to operate the business are not usually formal; and

- The market in which it operates is always imperfect.

There are therefore no generally accepted sets of criteria for defining what constitutes MSMEs qualitatively as different counties have their views.

\section{Quantitative Definitions of MSMEs}

Therefore, quantitative definitions of MSMEs are highly relative, depending on the objective of a study, an organization, or a country. They vary from one point to another [27]. Commonly, any attempt to define the concept is often premised on the size of their workforce, the total sales, and/or their asset worth [28, 29].

\section{MSMEs Growth Performance}

Yahaya, Osemene, and Selman [10] as cited in Akinruwa, Awolusi, and Ibojo [30] growth performance of MSMEs is their ability to create value for owners, managers, and other stakeholders. A firm can be successful in the market or produce expected outcomes based on expected actions [2]. Equally, GarrigosSimon, Marques, and Narangajavana [32] contend that growth performance could be assessed using four main features which are: (1) Profits generating ability of a firm (2) Growth of a business which could be measured using market share and business opportunities created by the firm. (3) The ability of the firm to satisfy its stakeholders, and (4) and how competitive advantageous a firm is.

However, the meaning of growth performance varies across organizations. Traditionally, it is assessed using financial indices such as profit, productivity, and return on investment. But more recently, the meaning of growth performance has been assessed using qualitative indicators. Just-in-time Delivery (JITD), Total Quality Management (TQM), the satisfaction of shareholders, and production of quality products $[32,33]$. This makes the conceptualization of MSMEs contain some degree of reliability as it could be measured quantitatively and qualitatively [34]. This corroborates with the views of Akinruwa, Awolusi, and Ibojo [30]. In all cases, past studies are of the view that regardless of business sizes, it is preferable to make use of various indices in 
assessing the growth performance of a firm [35-37]. Championing this assertion, Lumpkin and Dess [38] posit that, measuring the growth performance of a firm using a single perspective could be misleading.

Accordingly, this study adopts a balanced scorecard approach, which according to Kaplan and Norton [9], involves the use of quantitative and qualitative indices in assessing growth performance. Quantitative measures use profitability, sales, output, and employment growth, while the qualitative measure is the owner-managers' satisfaction with business performance. This is in tandem with the views of Atieno [40], who submit that a comprehensive objective measure should be used in assessing firms' growth performance. Briefly, these growth performance constructs-both quantitative and qualitative-are discussed hereunder:

\section{Profitability}

Profitability is the most used quantitative construct in measuring firms' growth performance [41]. When firms used profitability construct to assess their performance, the objective is to maintain or increase the earnings of the business through cost control measures, pricing policy, sales volume, inventory management, and capital expenditures. Edmister [42] and Thomas and Evanson [43] suggested that firms should rely on profitability as a measure of growth performance as the sole aim of any business is to make a profit. Though economic factors such as degree of competition among firms could affect business profit potentials, yet, low profitability gives firm's challenges, especially in terms of capitalization [44-47].

\section{Output Growth}

Growth outputs include three measures, namely: process measures, attribute measures, and measures of efficiency [48]. Each of the measures sees output growth as the total quantity of a good or service produced, or services offered which possess certain defined features (e.g., number of timely and accurate benefit payments). Typically, outputs are measured at least annually. Hudson and Bourne [49] are of the view that output growth should be used in assessing enterprise performance measurement as outputs correspond with the activities undertaken.

\section{Sales Growth}

Delmar et al., [50], on their part, posit that sales revenue should be seen as the true measure of firms' growth performance. Another rationale for using sales growth is that it is demand-based, which guarantees a steady demand for firms' products and/or services. Thus, an increase in sales or services offered would improve other aspects of the firm such as the employees and the cash-generating ability of the firm [51]. On the contrary, sales growth may also not be a reliable construct for appraising firms' performance. In the words of Delmar et al., [50], a small business that makes use of technology may experience an increase in their workforce and asset base than on sales growth.

\section{Employment Growth}

As Kimberley [52] stated, the number of people employed could also be used in assessing the performance of a firm. This is because the number of individuals employed reflects how organized and effective the internal workings of a firm is. Moreover, the number of employees a business has is hardly influenced by the frequent changes in inflation and exchange rates. As such, most scholars are of the view that it is not suitable for analyzing the growth potential of a firm [53]. The demerits of this construct, according to Delmar et al. [50] is that the number of individuals a business employs does not show if there is a corresponding increase in their productivity, the extent to which they can replace man with machine, their level of work integration.

\section{Owners' Satisfaction of Business}

Satisfaction is a qualitative measure of MSMEs performance. The dimensions of satisfaction, according to Cooper and Artz [54], include four features such as the extent to which the owner and managers are satisfied with sales, the extent to which they are satisfied with the profit, the general satisfaction of individuals involved, and their personal view on starting the same business again. Measuring how well the expectations of MSMEs' owners are met is an aspect of a balanced and holistic performance measurement approach that can provide critical insight and aid guidance for action [54]. The establishment of such a balanced stakeholder-based assessment is the mission and vision of a business [39].

The balanced stakeholder-based assessment approach provides an opportunity to ask questions such as:

- Who are the enterprise's owners?

- What do they expect of the enterprise?

- How well has the enterprise met these expectations?

\section{Accounting Practices}

Accounting practices are described as the routine manner whereby the day-to-day economic transactions of the financial nature of an organization are generated, collected, recorded, and analyzed. An MSMEs accounting practice refers to the way and manner by which its accounting information is utilized and adhere to on regular basis, typically by a professional accountant and/ or auditor or a team of accounting experts. It helps in the effective management of an organization as it provides essential information that is useful for effective managerial function in an organization. Without an effective accounting system, it would almost be impossible for a firm to appraise their performance, keep records of their customers and suppliers as well as predict their future 
performance using current organizational activities [55]. Nevertheless, an accounting system practiced by an organization should always be consistent with business operations to achieve consistently reliable financial reports which auditors might make use of.

\section{Thus, a good accounting system possesses the following features:}

i. It contains consistent records of firm revenue and expenditures;

ii. It contains records of purchases and sales;

iii. It contains the amount of overtime given to employees, depending on the computation method an organization chooses;

iv. Paying suppliers invoices on the day when they are due for settlement

v. It contains Just in Time Information (JIT) on the bills issues to customers; and

vi. It contains a uniform depreciation method for all non-current assets.

The development of a high level of accounting practices also calls for periodic evaluation of firms' business processes and procedures to spot errors and correct them as they occur. This could only be possible if firms can make use of best accounting practices to achieve effectiveness and efficiency as well as improve the fortune of the business over time. Expressing a similar view, Pavtar [56] argued that most MSMEs have a poor accounting system characterized by a lack of standard, hence, no proper assessment of their performances. This may engender poor management practices in an organization, leading to the possible failure of the firm eventually.

\section{The Concept of Financial Reporting Practices}

Operationally, this is defined as those procedures developed and installed by organizations' management to generate information about the activities of the reporting entity. Kalu [57] defined financial reporting as a means of providing accounting information regarding firms' profitability, growth, liquidity, activity, and financial stability and relating such information to the business stakeholders for effective decision making. Financial reporting practices, therefore, are seen as all the procedures, policies, and actions targeted at tracking, capturing, and recording of all transactions of monetary nature resulting in either generating cash flows or expending cash flows (that is, transactions involving cash inflows or outflows) from an entity. Etim [29] described financial reporting practices as accounting records, whereby firms record their business transactions regularly. This could also be called book-keeping. Altogether, gathering, preparation, and presentation of the needed information, under financial reporting practices, are all done using either the financial reporting system or the book-keeping system.
There are various forms of financial reporting systems. Accordingly, a few of them are discussed as shown hereunder:

\section{The Financial Accounting System}

Igben [58] defines a financial accounting system as the process of generating, storing, and explaining financial information on financial statements for the users of such information. When effectively done, it provides information on the data a given business transaction took place and full details of the transaction which would help in preparing the financial statement.

\section{The Auditing Practices System}

Uzuh [59] explains the auditing practices system from the prim of external and internal audits. According to him, external audits external viewpoints about the financial position of a firm, stating whether the firm is doing well or not. Other secondary objectives of external auditing include prevention of frauds and errors, reporting internal control weaknesses, and provision of valuable advice to the client on accounting and management issues.

External auditing may be statutory or private depending on why it is being conducted. Statutory audits as demand by law and falls within the confines of the companies and allied matters act, (CAMA) 1990, as amended. It is an audit made compulsory by the law, that is, it is not optional. The statute usually spells out the scope of audits work and cannot be limited by the entity or directors of the business entity. This type of audits is required of incorporated businesses. Private's audits are described as audits that are not compulsorily required by CAMA 1990 as amended. The details of work to be done are agreed upon between the client and the auditor. Audit of MSMEs fall under this class of audit.

Babatunde [60] defines internal audits as an independent evaluation of the activity within an organization for management use. This form of audit is required by all categories of businesses. Internal control system (ICS) to which interval audit is geared are used to achieve the following objectives: to achieve strict adherence to policies, to ensure effective and efficient management of a business, to protect the assets of an organization, and to ensure the accuracy and validity of the financial records. This corroborates with the assertion of Etim [29]. Critically assessing the above functions, it may be asserted that the auditing practices are needed by all MSMEs to sustain their operations and existence.

On the distinction between financial accounting and auditing practices, Uzuh [59] argues that accounting involves the safe-keeping of accounting records or transactions recorded in the various accounting books which could finally be used in the 
preparation of the financial statements of an enterprise at a particular date or point in time. In doing this, the role of the auditor is to give his/her independent opinion regarding how a business has been carried out based on the available accounting records.

\section{Cost/Management Accounting Practices}

MSMEs are into almost all types of ventures ranging from the agro-allied sector to manufacturing, Information and Communication Technology (ICT), petty to wholesale trading. Whichever sector they operate the basic costing and management accounting practices are required to be applied. Adeniyi [61] describes cost and management accounting practices as the preparation and presentation of accounting information that is required for effective managerial decision making. The cost and management accounting system helps in cost analysis, pricing, profitability analysis, project analysis, inventory planning, and control, and another decision-making purview necessary for organizational sustainability.

In general, the financial reporting framework which embraces the various accounting practices is tailored at providing data about the assets, liabilities, equities, gains, revenue, losses, expenses as well as profits either as they relate to the whole organization or a segment thereof. Also, all the activities of an entity whether large or small, require quantification in monetary terms to ascertain their financial implications in parts or whole as they affect the continual survival of the entity.

\section{The Concept of Sustainability}

As used in this study, sustainability is the ability of an MSME to continue in operation over a period after the business must have been established. It is assumed that the MSMEs will continue to exist for a long time as far as business transactions are recorded from this point of view. When applied in a broader sense, sustainability has to do with the management and coordination of all activities covering environmental, social, and financial demands and concerns to ensure the ethical and ongoing success of an entity over a reasonably long time frame [33]. It entails adopting an operational strategy that may cushion the effect of abrupt changes that can result in business failures and operational hitches. Thus, business sustainability as applied to MSMEs is the ability to mitigate possible causes of failure associated with the business environmental factors in which the entity operates.

\section{THEORETICAL FRAMEWORK}

In any research endeavor, several theories may be required that relate to the variables of the study and that form the base upon which a study is rested. This study is not an exemption, but the relevant theories for study are the "Going-concerns" concept and the Stakeholders' Theory.

\section{The Going-Concern Concept}

The International Accounting Standard Board (IASB) conceptual framework for financial reporting issues from time to time accounting standard for adoption when preparing and presenting financial statements. The framework contains some postulates or assumptions which have been used for a while in the preparation of financial statements based on acceptable principles. The Going-Concern concept is one of those concepts. It is based on the assumption that a business will operate as long as possible without any fear of liquidation. Thus, a business is said to be operating on this principle if their net income is positive yearly and seems not easily susceptible to external threats for the foreseeable future. The essence of this concept is that it is assumed that the entity (MSMEs) has neither the intention nor the need to liquidate or curtail materially its volume of operation. This is conceptually used and applied under this study as the concept of MSMEs sustainability [58].

\section{The Stakeholder Theory}

This theory was first proposed by R. Freeman [62] and stipulate how management can satisfy the interest of stakeholder in a business. In the field of business, stakeholder theory is often used to demonstrate the ethics and morals that are involved in the management of a firm. Though the theory talks about value and responsibility, yet, the ultimate objective of the theory is the need for management of an organization to satisfy the interest of the business owner or group of owners, individuals who are affected by their actions and inactions. Therefore, since stakeholders exercise a considerable level of influence or control over an organization's resources, they are obligated to provide the necessary information that will help the business owners for effective decision making [34].

These two theories are fundamental to the continual survival or sustainability of business (MSMEs) and are therefore considered relevant to this study.

\section{EMPIRICAL REVIEW}

This part of the study is devoted to the review of past studies in the areas of financial reporting practices and the sustainability of MSMEs. Financial reporting practices particularly financial accounting issues in the MSMEs sector have long attracted the attention of researchers and scholars. Thus, some of such studies are reviewed as shown hereunder:

i. Obara and Ukpai [63] examined the financial reporting practice of MSMEs concerning accounting information systems via cost accounting practices in the informal sector of Nigeria among 150 artisans. The researchers found that only nine (9) percent of the artisans kept and maintained costing records, while 91 percent did not. The study design was a survey 
and use of simple percentages to analyze the primary data obtained.

ii. Zotorvie [2] in a survey of financial accounting practices of Small and Medium Scale Enterprises (SMEs) in Ho municipality, Ghana, using a survey approach, administered a questionnaire to a total of 225 ownermanagers of SMEs in the region. The analysis involves frequency count and percentages. The result showed that the majority of SMEs failed due to poor accounting practices and as such cannot determine the value of their assets and liabilities, success or failure of the business over time. This study did not examine the possibility of SMEs failure form non-keeping of proper accounting records and adopting or non-adoption of some accounting practices

iii. Abusomwan and Oghogho [64] examined the importance of financial reporting and analysis; unfortunately, found that these practices are lacking, inadequate, and inappropriate among SMEs. There exists limited usage of financial reports that attributed to the inability to employ professional managers of SMEs with functional specializations in the financial area. They adopted a survey design approach in their study and concluded that SMEs are losing out without effective and adequate financial reporting and analysis practices. However, they did not investigate or analyzed the connection between inadequate or poor financial reporting practices and SMEs' bankruptcy and sustainability.

iv. Loikkanen [65] ascertained accounting-related practices of Finnish individual entrepreneurs in the context of electronic accounting (Eaccounting) adoption. Findings from the survey research show only about $2.3 \%$ of Finnish entrepreneurs embraced E-accounting practices in managing their accounting and cost-related activities. Thus, the researcher does not relate the continuity of existence of MSMEs to the adoption of E-accounting practices.

v. Etim [29] examined the relevance of accounting records in the development and sustainability of SMEs. Using the descriptive design, the objective of the study was to compare the existing conditions (practices) against standards of accounting practices by SMEs in Nigeria. Results confirmed the nonexistence of accounting records, nonpreparation, and analysis of financial statements as well as non-engagement of qualified personnel vested in accounting knowledge and skill by SMEs.

vi. Okafor and Daferighe [4] investigated accounting practices and performance of SMEs in Akwa Ibom State, Nigeria using a survey approach involving a questionnaire to gather data, which was analyzed using mean score and mean-scores averages and regression analysis. The results showed a strong linear relationship between accounting practices and the success of SMEs.

vii. In a similar study by Pavtar [56] on accounting practices of SMEs: Challenges and Effects; a survey of SMEs in Makurdi metropolis, Benue State, Nigeria, involving the adoption of survey research design and Chi-square statistic, findings shows SMEs mostly maintain sales and purchases records to the neglect of other accounting practices. He concluded that such neglect of accounting practices affected SMEs' survival and performance in that State.

viii. Muteti, Namusonge, and Nzomo [66] investigated accounting systems recordkeeping practices for SMEs development in Makueni country, Kenya. Primary data was used for the study which was administered to 250 small enterprise owners. The generated data were analyzed using both descriptive and inferential statistics. Results show evidence of a significant correlation between accounting systems and enterprise development in the Makueni country of Kenya. The study findings imply that enterprises with poor accounting systems would experience growth difficulty.

ix. Maseko and Manpani [21] studied the accounting practices of SMEs in Zimbabwe using the Bindura region as a case study. Data were collected through a survey design method involving 100 SMEs through the administration of a structured questionnaire. Data collected were analyzed using simple percentages and other descriptive statistics. The findings of the study revealed that the majority of SMEs do not keep accounting records due to a lack of accounting knowledge. They recommended that the national authorities should develop accounting guidelines for SMEs and undertake programs for the training of entrepreneurs of small businesses in basic accounting practices.

x. Adjer, Anokye, Mintah, and Offeh [67] studied financial reporting practices among small scale enterprises in Kumasi metropolitan region, Ghana. The research aimed to access the financial reporting practices among small scale enterprises in Ghana, West African. They also considered the problems faced by small scale enterprises in preparing financial reports. The researchers used both qualitative and quantitative research methods involving survey techniques of interviews, observation, and questionnaires. Data were analyzed using both descriptive and inferential statistics, and findings confirmed that there exist poor financial record keeping and financial 
reporting practices among small scale enterprises and recommend that training programs be organized for small scale entrepreneurs to help them appreciate the importance of financial reporting and inculcate such practices in them.

xi. Rathnasiri [68] investigated the financial reporting practices of SMEs in Sri Lanka's using a sample of 60 SMEs which were registered with the Ministry of Industry and Commerce (MIC) for the period 2008 to 2013 and operating their business in the manufacturing sector in the Western Province of Sri Lanka.He employed a survey design research method using a questionnaire to collect data which were analyzed using descriptive statistics involving the calculation of average, frequency distribution, crosstabulations, and percentage distribution. The results revealed that most SMEs give more consideration to the preparation and monitoring of three financial statement components comprising the statement of financial position, income statement, and statement of cash flows which are critical to their success and survival. Results show a strong positive relationship between financial reporting practices and performance assessment and survival of SMEs in Sri Lanka.

xii. Boame, Kudadze, and Suleman [69] conducted a study on the adoption of accounting practices and their effects on small and medium scale (SMEs) performance: the financial perspective of sachet water producers in the Northern Region of Ghana. A qualitative research design was employed and a non-probability sampling design of convenience sampling method was employed to gather the data. Data were gathered from both primary and secondary sources. 30 registered small scale sachet water producers were sampled from the northern sachet water producers association by administering the semi-structured questionnaire and personal interviews. Data collected were analyzed using descriptive statistical tools with results revealing that many perceived factors affect the adoption of accounting practices which included lack of adequate training, willful misconduct, and negligence with illiteracy as the root cause of the problems. Their findings also included non-documentation of cash sales, the error of principle, incomplete entry of financial records, inability to separate personal expenses from business expenses among other accounting practices shortcomings, and recommended the hiring of accounting professional to help reverse some of the trends. xiii. Furthermore, another study was carried out on accounting practices and control systems of small and medium-size entities in the Techiman Municipality of Ghana (Ntim, Evans, and Anthony [70]. The researchers employed a descriptive approach with a combination of the stratified sampling technique and the purposive sampling technique. They used 150 samples involving interviews and questionnaires. They gathered and analyzed data that revealed that SMEs do keep accounting books in recording their business transactions. It further revealed that SMEs do not maintain all the required books of original entry. The findings also revealed that most SMEs maintained fixed assets (Noncurrent asset) register than all other books of original entry. Cash tallied was the next book kept by most SMEs whereas petty cashbook was identified as the rare book maintained by SMEs. Again, the study identified that there is a direct relationship between the firms' size identified that, there is a direct relationship between firm's size and the types of books kept. Micro firms (1 to 6 employees) usually kept 1 to 3 books, whereas medium-sized enterprises (31-50 employees) kept 5 and 6 books. These study findings go to confirm assertions made by some research findings that the size of the firm influences the types of books of accounts to be kept and the accounting practices in place.

xiv. Adjei [67] reviewed financial records in small firms and concluded that financial record of SMEs should include; sales day book, purchase day book, cash receipt book, cheque payment book, petty cash book, general journal, nominal ledger, debtors' ledger, and creditors' ledger. Accounting and marketing pose major challenges to the management of SMEs and recommended that managers or owners of SMEs must learn about accounting or hire experts. Conventional accounting reports play a significant role in SMEs but argue that the reports must be adjusted for them to be understood, proposing the use of the cash basis rather than the accruals basis of accounting.

xv. Hamza, Mutala, and Stephen [71] surveyed 300 SMEs located in the Northern Region of Ghana; using descriptive and inferential statistics, the researchers demonstrated that SMEs' financial performance was positively correlated with efficiency in inventory management. They also pointed out that, there was a need for managers of SMEs to embrace efficient inventory management practices as a strategy for improving their financial performance and survival in that currently uncertain on short-term borrowing, the volatility of cash and profit position are some of the core necessities for applying basic 
accounting practices such as inventory, credit, debt and cash management practices among SMEs.

\section{The gap in the Literature}

In all the past studies reviewed which were carried out in Nigeria and internationally, none of these studies examined fully financial reporting practices and sustainability of MSMEs in Akwa Ibom State, as found by the researcher. More so, these studies mostly concentrated on one form of financial accounting practices and performances of MSMEs. However, this study attempts to assess the relationship between financial reporting practices and the sustainability of MSMEs in Akwa Ibom State.

\section{METHODOLOGY}

This chapter of the study centers on the research methods, which deals with how the study will be conducted, how data collection will be generated, the tools for data collection, among others.

\section{Research Design}

A survey research design is adopted in the study. The plan was to obtain first-hand information via questionnaire with owner-manager of they would be selected MSMEs. This was to enable us to describe the financial reporting practices adopted by the management of the enterprises and to test the relationship between the practices and sustainability of MSMEs.

\section{Population of the Study}

The population of the study comprised of all MSMEs duly registered in Akwa Ibom State as listed in 2018 [72]. SMEDAN is the Coordinating Agency for all matters about the MSMEs sub-sector in Nigeria.

According to SMEDAN [72] report, there are 447,903 MSMEs in Akwa Ibom State as shown in the table below:

\section{Table-1: Composition of MSMEs as Reported by} SMEDAN

\begin{tabular}{|l|c|c|}
\hline Types of Enterprise & No & \% \\
\hline Micro & 447,589 & 99.93 \\
\hline Small & 275 & 0.06 \\
\hline Medium & 39 & 0.01 \\
\hline Total & 447903 & 100 \\
\hline
\end{tabular}

Source: SMEDAN Report, 2018

\section{Sample and Sampling Technique}

The number of MSMEs studied are drawn in a three-stage sampling process. First, a stratified sampling technique was used to ensure that the three sub-sectors of MSMEs (Micro, Small and Medium enterprise) are represented accordingly. Second, to make for effective and objective coverage, sampled businesses were selected from the four major towns of Akwa Ibom State-Uyo, Ikot Ekpene, Eket, and Oron. Third, the
Taro Yamane formula for sample size determination given as:

$n=\frac{N}{1+N(e)^{2}}$

Where:

$\mathrm{N}=$ Population

$\mathrm{n}=$ Sample Size

$\mathrm{e}=$ error margin at $10 \%$ or 0.1

$1=$ constant

The Taro Yamane sample size determination technique was used to determine the exact sample under each category of the enterprise. Finally, random sampling was employed to select the MSMEs studied. The number of each class of enterprises to be selected is calculated as follows:

Micro-Enterprise

$$
n=\frac{447589}{1+447589(0.1)^{2}} \quad=99.98 \approx 100
$$

Small Enterprise

$$
n=\frac{275}{1+275(0.1)^{2}}=56
$$

Medium Enterprise

$$
n=\frac{39}{1+39(0.1)^{2}}=29
$$

The random sampling selection of the MSMEs for the study is the premise on the fact that these businesses have features or characteristics that are similar, hence, the result can be generalized.

\section{Sources of Data for the Study}

Insourcing for the needed primary data, a structured questionnaire was used. The questionnaire is designed in two sections: section ' $A$ ' addresses 'BIOdata' of respondents while section ' $\mathrm{B}$ ' is on the financial reporting practices and sustainability of SMEs, considering three key areas of financial accounting practices, auditing practices, and cost/management accounting practices.

\section{Theoretical and Empirical Specification of Model}

The study is on financial reporting practices and the sustainability of MSMEs. The theoretical model developed is shown as follows;

MSMES SUS $=f f R P-\cdots-$-Equation - 3.1

Where,

MSMES SUS = Sustainability of MSMES ability of MSMEs to sustain their operations. $F R P=$ Financial Reporting Practices 
The model is stated as:

Sus $=\alpha_{0}+\alpha_{1} \alpha_{1}+\alpha_{2} \alpha_{2}+\alpha_{3} \alpha_{3}+\ldots \mu$ - - Equation - - 3.2

Where,

Sus $=$ Sustainability (dependent variable)

$\alpha_{1}-\alpha_{3}=$ independent variables (financial reporting practices)

Specifically, the model for this study is stated as:

Sus $=a_{0}+a_{1} F A_{p}+a_{2} A u d_{p}+a_{3} C A m_{p}+\ldots \mu$--Equation - 3.3
Where:

Sus = MSMEs Sustainability proxy by business that have survived from five years and above from incorporation or commencement of operations.

$a_{0}=$ Constant

$a_{1} F A_{P}=$

Coefficient of financial accounting practices

$a_{2} A u d_{P}=$ Coefficient of auditing practices

$a_{3} C A M_{P}=$

Coefficient of cost management accounting practices

$N=$ Stochastic error factor

Table-2: Theoretical Specification of Model and Apriori Expectation

\begin{tabular}{|l|l|c|c|}
\hline S/N & Variable & Abbreviation used & Apriori Expectation \\
\hline 1 & Sustainability & Sus. & \\
\hline 2 & Financial Accounting Practice & FAP & + \\
\hline 3 & Auditing Practice & AUDP & + \\
\hline 4 & Cost Management Accounting Practices & CAMP & + \\
\hline
\end{tabular}

Source: Researcher compilation, 2020.

\section{Validity and Reliability of Instrument}

To determine the content validity of the questionnaire, a pilot test was conducted after which the Cronbach alpha reliability was calculated to test for the reliability of the instrument. Thus, test-re-test and content validity by the supervisor. To accept the instrument as reliable, the Cronbach alpha coefficient must be above 0.5 ; in this case, it was 0.89

\section{METHOD OF DATA ANALYSIS}

The descriptive statistics, simple and multiple linear Regression, R-Square, Adjusted-R-Square, tstatistics (t-stat), Durbin-Watson (D-W) statistics, Frate for ANOVA, and P-value will be used to analyze the generated primary data at a $5 \%$ level of significance.

\section{Data Presentation, Analysis, and Findings}

This section of the study centered on the presentation of primary data that were generated in the course of the study. Thereafter, major findings from the data analyzed were equally discussed. Altogether, this section of the study was considered under the following sub-headings: data presentation, analysis of commonly adopted financial reporting practices, the test of hypothesis/analysis, and discussion of findings. These features of the study were presented as shown hereunder:

\section{Data Presentation and Analysis}

Primary data generated by the respondents were presented in this section of the study. The responses were structured using a 5-point rating scale of No. Extent (NE) - Very large Extent (VLE). This was spread evenly across all the variables of sustainability, financial accounting practices, auditing practices, and cost/management accounting practices. The responses generated in this regard were presented in APPENDIX 1 and explained as shown hereunder.

\section{Analysis of Commonly Adopted Financial Reporting Practices by MSMEs}

The main objective of this study was to ascertain the linkage between financial reporting practices and sustainability of micro, small, and medium scale enterprises (MSMEs) in Akwa Ibom State. Consequent upon this objective, descriptive analysis is carried out to evaluate the commonly adopted financial reporting practices under three subheadings of financial accounting practices, auditing practices, and cost/management accounting practices. Each of the practices was analyzed using the modified Likert Scale with weights. Points ranging between 0 and 4 for "no extent" NE - o, 'Low Extent' LE - I, 'moderate extent' ME-2, 'Large - Extent' LGE-3 ad 'very large extent' VLE - 4, respectively.

Accordingly, each of the independent variables is analyzed with relevant question variables (keywords) relating to the practice. 
Table-3: Responses on Financial Accounting Practices $\left(\mathbf{X}_{1}\right)$

\begin{tabular}{|l|l|l|l|l|l|l|l|}
\hline & $\begin{array}{l}\text { Weight /Scale /Total Weighted Responses } \\
\text { ( ) Questions (see Appendix for Details) }\end{array}$ & $\mathbf{0}$ & $\mathbf{1}$ & $\mathbf{2}$ & $\mathbf{3}$ & $\mathbf{4}$ & AVERAGE \\
\hline 1 & $\begin{array}{l}\text { Extent of Adoption of Cash/Book Keeping } \\
\text { Practices }\end{array}$ & $\begin{array}{l}0 \\
(0)\end{array}$ & $\begin{array}{l}10 \\
(10)\end{array}$ & $\begin{array}{l}62 \\
(124)\end{array}$ & $\begin{array}{l}61 \\
(183)\end{array}$ & $\begin{array}{l}49 \\
(196)\end{array}$ & $513(102.6)$ \\
\hline 2 & Extent of adoption of banking transactions & 0 & 35 & 57 & 65 & 27 & \\
& $(0)$ & $(35)$ & $(114)$ & $(195)$ & $(108)$ & $452(90.4)$ \\
\hline 3 & $\begin{array}{l}\text { Extent of carrying out bank reconciliation } \\
\text { statements }\end{array}$ & $\begin{array}{l}0 \\
(0)\end{array}$ & $\begin{array}{l}73 \\
(73)\end{array}$ & $\begin{array}{l}80 \\
(160)\end{array}$ & $\begin{array}{l}20 \\
(60)\end{array}$ & $\begin{array}{l}11 \\
(44)\end{array}$ & $337(67.4)$ \\
\hline 4 & Extent of preparation of financial statements & 0 & 73 & 80 & 20 & 11 & \\
& & $(0)$ & $(73)$ & $(160)$ & $(60)$ & $(44)$ & $337(67.4)$ \\
\hline 5 & $\begin{array}{l}\text { Extent of maintenance of sales and } \\
\text { purchases records }\end{array}$ & 0 & 71 & 75 & 16 & 22 & \\
$(0)$ & $(71)$ & $(150)$ & $(48)$ & $(88)$ & $357(71.4)$ \\
\hline
\end{tabular}

Source: Researcher's Computation from Field Survey Data, 2020.

From Table 3, which discloses the respective responses on financial accounting practices mostly carried out by MSMEs' operator, cash/book-keeping a mean score of 10.2 points, followed by banking transactions with an average score of 90.4 and maintenance of sales and purchases records scoring
71.4 average points while bank reconciliation and preparation of financial statements score 67.4 average points each. It portrays that cash/book-keeping practices constitute the common practice activity among the five activities selecting under this category of financial reporting practices.

Table-4: Responses on Financial Accounting Practices $\left(X_{1}\right)$

\begin{tabular}{|c|c|c|c|c|c|c|c|}
\hline & $\begin{array}{l}\text { Weight /Scale /Total Weighted } \\
\text { Responses ( ) } \\
\text { Questions (see Appendix for Details) }\end{array}$ & $\mathbf{0}$ & 1 & 2 & 3 & 4 & AVERAGE \\
\hline 1 & Extent reliance on Internal Audit services & $\begin{array}{l}103 \\
(0)\end{array}$ & $\begin{array}{l}50 \\
(50)\end{array}$ & $\begin{array}{l}20 \\
(60)\end{array}$ & $\begin{array}{l}20 \\
(60)\end{array}$ & $\begin{array}{l}1 \\
(4)\end{array}$ & $154(30.8)$ \\
\hline 2 & Extent of Independence of Internal Auditor & $\begin{array}{l}153 \\
(0)\end{array}$ & $\begin{array}{l}35 \\
(35)\end{array}$ & $\begin{array}{l}20 \\
(60)\end{array}$ & $\begin{array}{l}20 \\
(60)\end{array}$ & $\begin{array}{l}1 \\
(4)\end{array}$ & $104(20.8)$ \\
\hline 3 & $\begin{array}{l}\text { Extent of Effectiveness of Organisation's } \\
\text { Internal Control }\end{array}$ & $\begin{array}{l}153 \\
(0)\end{array}$ & $\begin{array}{l}73 \\
(73)\end{array}$ & $\begin{array}{l}20 \\
(60)\end{array}$ & $\begin{array}{l}20 \\
(60)\end{array}$ & $\begin{array}{l}1 \\
(4)\end{array}$ & $104(20.8)$ \\
\hline 4 & $\begin{array}{l}\text { Extent International Control Officer review } \\
\text { Operational Procedures }\end{array}$ & $\begin{array}{l}153 \\
(0)\end{array}$ & $\begin{array}{l}73 \\
(73)\end{array}$ & $\begin{array}{l}20 \\
(60)\end{array}$ & $\begin{array}{l}20 \\
(60)\end{array}$ & $\begin{array}{l}1 \\
(4)\end{array}$ & $104(20.8)$ \\
\hline 5 & $\begin{array}{l}\text { Extent of Usage of Services of External } \\
\text { Auditor on annual reports: }\end{array}$ & $\begin{array}{l}153 \\
(0)\end{array}$ & $\begin{array}{l}40 \\
(40)\end{array}$ & $\begin{array}{l}0 \\
(0)\end{array}$ & 0 & 1 & $44(8.8)$ \\
\hline
\end{tabular}

From Table 4, which reflect the extent of carrying out auditing practices by MSMEs, the average scores were $30.8,20.8,20.8,20.8$, and 8.8 for the extent of reliance on internal audit, the extent of independence of the internal auditor, the extent of effectiveness of organization's internal control, extent internal control officer review operational procedures and extent of usage of services of the external auditor on annual report respectively. The summarized positioning here is that these groups of business operators do not embrace auditing practices to a large extent, hence the low average scores for each construct under this category of financial reporting practices.

Table-5: Responses on Cost/Management Accounting Practices $\left(\mathbf{X}_{\mathbf{3}}\right)$

\begin{tabular}{|c|c|c|c|c|c|c|c|}
\hline & $\begin{array}{l}\text { Weight /Scale /Total Weighted Responses（ ） } \\
\text { Questions (see Appendix for Details) }\end{array}$ & $\mathbf{0}$ & 1 & 2 & 3 & 4 & AVERAGE \\
\hline 1 & Extent of preparation of cash budget & $\begin{array}{l}48 \\
(0)\end{array}$ & $\begin{array}{l}32 \\
(32)\end{array}$ & $\begin{array}{l}48 \\
(96)\end{array}$ & $\begin{array}{l}24 \\
(72)\end{array}$ & $\begin{array}{l}32 \\
(128)\end{array}$ & $328(65.6)$ \\
\hline 2 & Extent of carrying out cost analysis & $\begin{array}{l}69 \\
(0)\end{array}$ & $\begin{array}{l}61 \\
(61)\end{array}$ & $\begin{array}{l}14 \\
(28)\end{array}$ & $\begin{array}{l}30 \\
(90)\end{array}$ & $\begin{array}{l}10 \\
(40)\end{array}$ & $219(43.8)$ \\
\hline 3 & $\begin{array}{l}\text { Extent organization conduct product/segment } \\
\text { profitability analysis }\end{array}$ & $\begin{array}{l}70 \\
(0)\end{array}$ & $\begin{array}{l}64 \\
(64)\end{array}$ & $\begin{array}{l}24 \\
(48)\end{array}$ & $\begin{array}{ll}20 \\
(60)\end{array}$ & $\begin{array}{l}10 \\
(40)\end{array}$ & $212(42.4)$ \\
\hline 4 & Extent organization prepare forecast: & $\begin{array}{l}70 \\
(0)\end{array}$ & $\begin{array}{l}64 \\
(64) \\
\end{array}$ & $\begin{array}{l}24 \\
(48)\end{array}$ & $\begin{array}{l}20 \\
(60)\end{array}$ & $\begin{array}{ll}10 \\
(40)\end{array}$ & $212(42.4)$ \\
\hline 5 & $\begin{array}{l}\text { Extent organization adopt capital budgeting } \\
\text { technique to appraise projects }\end{array}$ & $\begin{array}{l}70 \\
(0)\end{array}$ & $\begin{array}{l}51 \\
(51)\end{array}$ & $\begin{array}{l}37 \\
(74)\end{array}$ & $\begin{array}{l}20 \\
(60)\end{array}$ & $\begin{array}{l}10 \\
(40)\end{array}$ & $225(45.0)$ \\
\hline
\end{tabular}

Source: Researcher's Computation from Field Survey Data, 2020 
From Table 5, among the cost/management accounting practices, the practice with the highest average score is the preparation of cash budget with a mean score of 65.6 points. Others had average scores of 45.0, 43.4, and 42.4 for capital budgeting technique, cost analysis, product/segment profitability analysis, and preparation of operational forecast respectively. On the whole, these activities are not well embraced by MSMEs operators in Akwa Ibom State.

\section{Test of Hypotheses}

In the course of this study, four (4) null hypotheses were formulated. The formulated null hypotheses were all tested in this section of the study as follows:

Test of Hypothesis 1

$\mathbf{H}_{01}$ : Financial accounting practices do not affect the sustainability of Micro, Small, and Medium Scale Enterprises (MSMEs). Simple linear regression was used in testing hypothesis one. In the course of the analysis, financial accounting practices were used as the independent variable while the sustainability of Micro, Small, and Medium Scale Enterprises (MSMEs) was used as the dependent variable. Thus, the result of hypothesis one was presented as follows:

Table-6: Regression Result of Hypothesis One

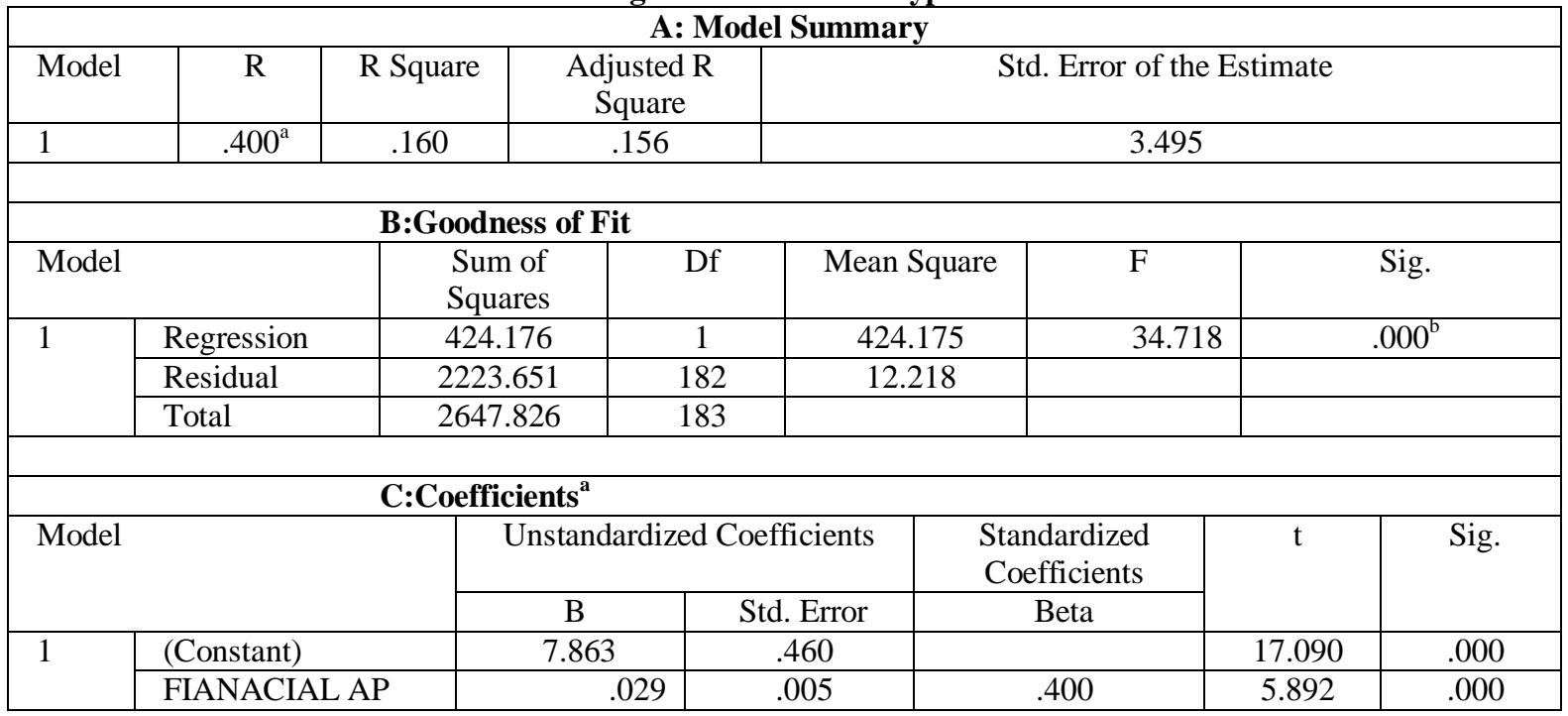

Source: Researcher's computation, 2020 using SPSS version 20.0.

The table above shows the result of hypothesis one. From the Table (Table 6a: Model Summary), the correlation coefficient (r) which shows the relationship between financial accounting practices and sustainability of Micro, Small and Medium Scale Enterprises (MSMEs) is 0.400. This shows that there is a positive and significant relationship between the two correlated variables. Also, the Table shows the value of the coefficient of determination $\mathbf{R}^{2}$ which explains changes in the dependent variable that is caused by changes in the independent variables as 0.160 . This evidenced the fact that the independent variable (financial accounting practices) used in the model can explain $16 \%$ variation in the sustainability of Micro, Small, and Medium Scale Enterprises (MSMEs).

Furthermore, the Table shows the goodness of fit (Table 6b: Goodness of Fit) between the regressed variables. The F statistics have a value of 34.718 with a corresponding p-value of 0.000 , which is less than the 0.05 level of significance $(\mathrm{P}<0.05)$. This further strengthened the fact that the regressed variables are significant and also exhibit goodness of fit between them. Equally, the $\beta$ value of the analysis is 0.400 with a $\mathrm{t}$ value of 5.892 and a p-value of 0.000 (Table 6c:
Coefficient), which is less than the 0.05 level of significance $(\mathrm{P}<0.05)$. This buttressed that the independent variable (financial accounting practices) has a positive effect on the sustainability of Micro, Small, and Medium Scale Enterprises (MSMEs). Statistically, it shows that the independent variable (financial accounting practices) could explain $40 \%$ changes in the dependent variable (sustainability of MSMEs) while $60 \%$ could be explained by other factors not captured in the model. This is corroborated by the study of Etim [29] and Ankarah, Mensah, and OfforiAttah [13] who found a positive relationship between accounting records keeping and sustainability of SMEs.

\section{Test of Hypothesis Two}

$\mathbf{H}_{\mathbf{0 2}}$ : Auditing practices have no significant relationship with the sustainability of Micro, Small, and Medium Scale Enterprises (MSMEs). Hypothesis two was analyzed using simple linear regression. The essence was to establish both the relationship as well as the causal relationship between the two variables (auditing practices and sustainability of MSMEs). The result of the analysis was presented as shown hereunder: 
Table-7: Regression Result of Hypothesis Two

\begin{tabular}{|c|c|c|c|c|c|c|}
\hline \multicolumn{7}{|c|}{ A: Model Summary } \\
\hline Model & $\mathrm{R}$ & R Square & Adjusted R Square & \multicolumn{3}{|c|}{ Std. Error of the Estimate } \\
\hline 1 & $.036^{\mathrm{a}}$ & .001 & -.004 & \multicolumn{3}{|l|}{3.812} \\
\hline \multicolumn{7}{|c|}{ B:Goodness of Fit } \\
\hline \multicolumn{2}{|l|}{ Model } & Sum of Squares & Df & Mean Square & $\mathrm{F}$ & Sig. \\
\hline \multirow[t]{3}{*}{1} & Regression & 3.457 & 1 & 3.456 & 0.238 & $0.626^{b}$ \\
\hline & Residual & 2644.369 & 182 & 14.530 & & \\
\hline & Total & 2647.826 & 183 & & & \\
\hline \multicolumn{7}{|c|}{ C:Coefficients ${ }^{\mathrm{a}}$} \\
\hline \multirow{2}{*}{\multicolumn{2}{|c|}{ Model }} & \multicolumn{2}{|c|}{ Unstandardized Coefficients } & Standardized Coefficients & \multirow[t]{2}{*}{$\mathrm{t}$} & \multirow[t]{2}{*}{ Sig. } \\
\hline & & $\mathrm{B}$ & Std. Error & Beta & & \\
\hline \multirow[t]{2}{*}{1} & (Constant) & 10.274 & 0.440 & & 23.371 & 0.000 \\
\hline & AUDITING PRAT & -.005 & 0.011 & -.400 & -.488 & 0.626 \\
\hline
\end{tabular}

Source: Researcher's computation, 2020 using SPSS version 20.0.

The above Tables (Table 7A: Model Summary; Table 7B: Goodness of Fit; Table 7C: Coefficients) shows the relationship as well as the effects the independent variable (auditing practices) has on the dependent variable (sustainability of MSMEs). Looking at Table (Table 7A: Model Summary), the relationship between auditing practices and the sustainability of MSMEs has a correlation coefficient (r) of 0.036. This indicates that there is a low but positive relationship between the correlated variables. Accordingly, the Table further shows the coefficient of determination $\mathbf{R}^{2}$ to be 0.001 , which shows that a unit change in the dependent variable (sustainability of MSMEs) is caused by a $0.1 \%$ change in the independent variable (auditing practices).

Table 7B shows the goodness of fit between the regressed variables. From the Table, the F statistics have a value of 0.238 with a corresponding $p$-value of 0.626 which is greater than $0.05(p>0.05)$. This shows that the regressed variables are not significant as such, there is no goodness of fit between the variables. More so, the $\beta$ value of -.036 with a $t$ value of -.488 and $p$ value of 0.626 , which is greater than $0.05(\mathrm{p}>0.05)$ shows that the independent variable (auditing practices) has a moderate and negative effect on the dependent variable (sustainability of MSMEs). This implies that for any unit change in the dependent variable (sustainability of MSMEs), the independent variable (auditing practices) contributed $-36 \%$. This means that most of the MSMEs studied, and in general do not embrace the auditing practices and do not have internal audit units in their organizations. This result contrasts the findings of Mbroh and Attom [73] that found a positive relationship between variables in their SMEs study of Cape Town Ghana.

\section{Test of Hypothesis Three}

$\mathbf{H}_{\mathbf{0 3}}$ : Cost and management accounting practices have no significant relationship with the sustainability of Micro, Small, and Medium Scale Enterprises (MSMEs). Hypothesis three was analyzed using simple linear regression. The rationale was to establish a relationship between the regressed variables as well as to determine the effects the independent variable (cost and management accounting practices) have on the dependent variable (Sustainability of MSMEs). Altogether, the result of the analysis was presented thus:

Table-8: Regression Result of Hypothesis Three

\begin{tabular}{|c|c|c|c|c|c|c|}
\hline \multicolumn{7}{|c|}{ A: Model Summary } \\
\hline Model & $\mathrm{R}$ & R Square & Adjusted R Square & \multicolumn{3}{|l|}{ Std. Error of the Estimate } \\
\hline 1 & $0.013^{\mathrm{a}}$ & 0.000 & -.005 & \multicolumn{3}{|l|}{3.814} \\
\hline \multicolumn{7}{|c|}{ B:Goodness of Fit } \\
\hline \multicolumn{2}{|l|}{ Model } & Sum of Squares & Df & Mean Square & $\mathrm{F}$ & Sig. \\
\hline \multirow{3}{*}{1} & Regression & 0.459 & 1 & 0.459 & 0.032 & $0.856^{\mathrm{b}}$ \\
\hline & Residual & 2647.367 & 182 & 14.546 & & \\
\hline & Total & 2647.826 & 183 & & & \\
\hline \multicolumn{7}{|c|}{ C:Coefficients ${ }^{\mathrm{a}}$} \\
\hline \multirow{2}{*}{\multicolumn{2}{|c|}{ Model }} & \multicolumn{2}{|c|}{ Unstandardized Coefficients } & $\begin{array}{l}\text { Standardized } \\
\text { Coefficients }\end{array}$ & $\mathrm{t}$ & Sig. \\
\hline & & B & Std. Error & Beta & & \\
\hline \multirow[b]{2}{*}{1} & (Constant) & 10.034 & 0.504 & & 19.897 & 0.000 \\
\hline & $\begin{array}{l}\text { AUDITING } \\
\text { PRAT }\end{array}$ & 0.002 & 0.009 & 0.013 & 0.178 & 0.859 \\
\hline
\end{tabular}

Source: Researcher's computation, 2020 using SPSS 20.0 version 
Table 8 depicts the regression result of hypothesis three being analyzed. Looking at the Table (Table 8A: Model Summary), the correlation coefficient (r) which shows the relationship between the dependent variable (sustainability of MSMEs) and the independent variable (cost and management accounting practices) is 0.013 . This value shows that there is a low but positive relationship between the regressed variables. This result is further buttressed by the value of the coefficient of determination $\mathbf{R}^{2}$ which is 0.000 .

Accordingly, Table 8 (Table 8B: Goodness of Fit) shows the goodness of fit between the variables regressed. Looking at the Table, F-statistic has a value of 0.032 with a corresponding p-value of 0.858 , which is greater than the 0.05 level of significance $(p>0.05)$. This shows that the result of the regressed variables is not significant as such, there is no goodness of fit between them. Furthermore, the $\beta$ value of 0.013 with a $\mathrm{t}$ value of 0.178 and $\mathrm{p}$-value of 0.859 , which is greater than 0.05 ( $p>0.05)$ shows that the independent variable (cost and management accounting practices) has a low and positive effect on the dependent variable (sustainability of MSMEs). This implies that for any unit change in the dependent variable (sustainability of
MSMEs), the independent variable (cost and management accounting practices) contributed $1.3 \%$. Thus, there is no significant relationship between the variables regressed.

In general, the findings here revealed that MSMEs moderately adopt cost/management accounting practices in their operations. The result is confirmed by earlier studies conducted by Mbogo [74], and Obara and Ukpai [63] who also reported low adoption of cost and management accounting techniques in their researches.

\section{Test of Hypothesis Four}

$\mathbf{H}_{\mathbf{0 4}}$ : The joint effect of financial accounting, auditing, and cost/management practices does not significantly affect the sustainability of Micro, Small, and Medium Scale Enterprises (MSMEs). Hypothesis three was analyzed using multiple regressions. The rationale that informed the use of multiple regressions was to ascertain the effects of the independent variables that were previously analyzed has on the dependent variable when analyzed jointly. The result of the analysis was presented as shown thus:

Table-9: Regression Result of Hypothesis Four

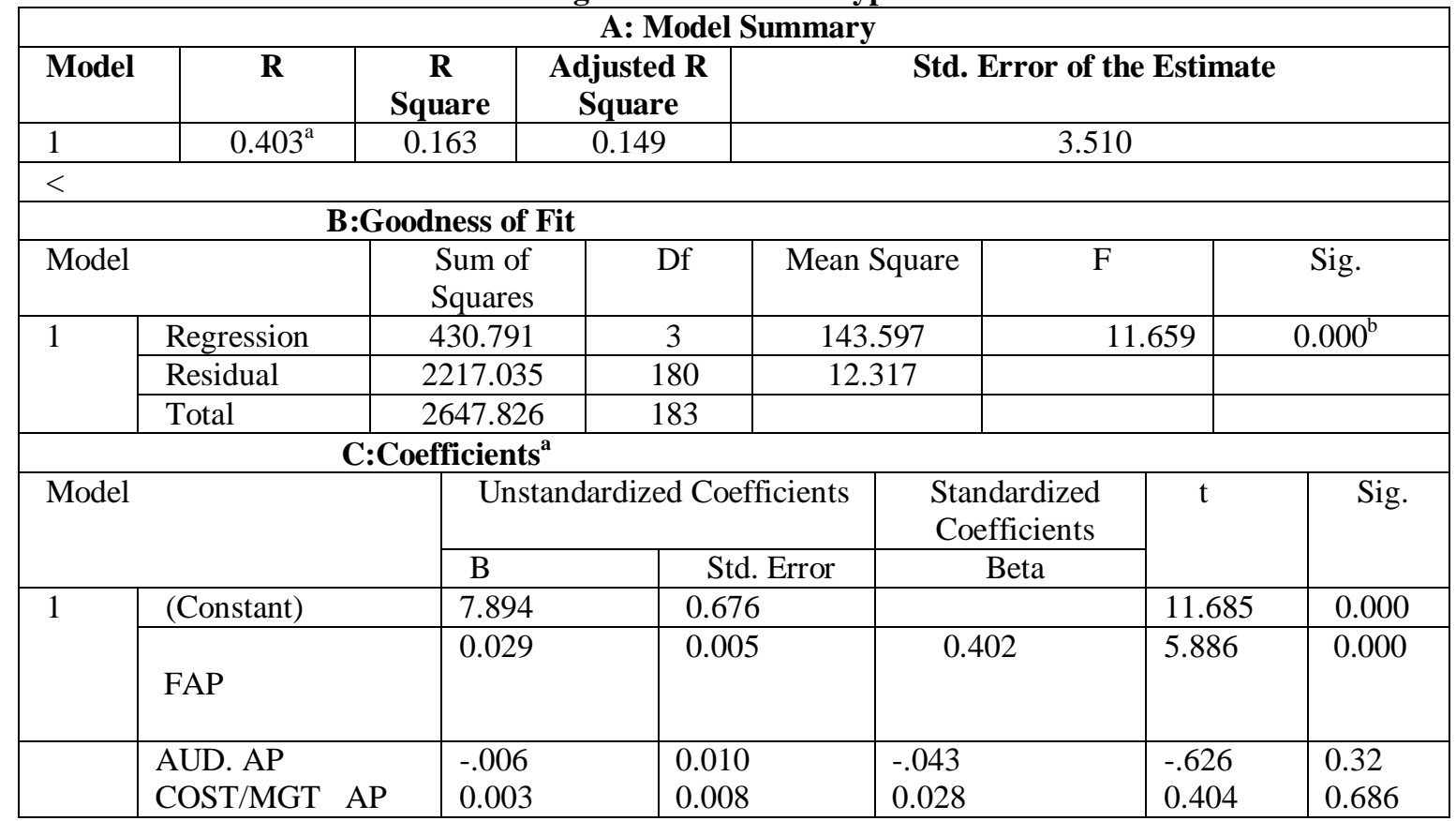

Source: Researcher's computation, 2020 using SPSS version 20.0.

Table 9 above (Table 9A: Model Summary; Table 9B: Goodness of Fit; Table 9C: Coefficients) shows the multiple regression of hypothesis one. Looking at the Table (Table 9A: Model Summary), the correlation coefficient ( $\mathrm{r}$ ), which shows the relationship between the regressed is 0.403 . This value indicates that there is a positive and significant relationship between the variables being regressed. Equally, the value of the coefficient of determination $\mathbf{R}^{\mathbf{2}}$ is 0.149 . This shows that changes in the dependent variable could be explained by a $14.9 \%$ change in the independent variables when tested jointly.

Similarly, Table 9B shows the goodness of Fit Table. The $\mathbf{F}$ statistic has a value of 11.659 with a corresponding p-value of 0.000 , which is less than 0.05 $(\mathbf{p}<\mathbf{0 . 0 5})$. This strengthened the point that there is the existence of goodness of fit among the regressed 
variables. More so, the $\boldsymbol{\beta}$ values of $0.402,-.043$ and 0.028 with corresponding $\mathbf{t}$ values of $5.886,-.626$ and 0.404 and p-values of $0.000,0.532$, and 0.686 which is both less and greater than $0.05(\mathbf{p}>\mathbf{0 . 0 5})$ show that the independent variables (financial accounting, Auditing practices, and cost/management accounting practices) when regressed jointly, has mixed results. The analysis shows a significant, negative, and low effect of the independent variables on the dependent variable (sustainability of MSMEs). Altogether, this implies that when tested jointly, only financial accounting practices exhibit a significant effect $(\boldsymbol{\beta}=0.402)$ on the dependent variable (sustainability of MSMEs) with $40.2 \%$. This finding is affirmed by the study of Mintah, Nayfordadjei, and Anokeye [15] who carried out their study in Kumasi, Ghana, and found positive relationships among variables studied.

\section{Discussion OF Findings}

The study was conceived to empirically investigate financial reporting practices and sustainability of MSMEs in Akwa Ibom State. To achieve the overall objective, three major financial reporting practices were isolated for the study, and five (5) key practices under each identified and sued for developing the research instrument. The three major financial reporting practices are: financial accounting practices under each identified and sued for developing the research instrument. The three major financial reporting practices are; financial accounting practices, auditing practices, and cost/management accounting practices. The selection of these practices is carried out bearing in mien both internal and external users of financial reporting information.

From the findings of the study, among the five (5) construct under financial accounting practices (cash/bookkeeping, banking transactions, bank reconciliation statements, preparation of financial statements, and maintenance of sales and purchases records), adoption of cash and bookkeeping practices were the most common practices. Although on average, all practices had an average score of above $50 \%$. This was further confirmed by the regression analysis results that there exists a positive relationship between financial accounting practices and the sustainability of MSMEs in the area of study.

On the practices relating to auditing and sustainability of MSMEs (the constructs were: reliance on internal audit, independence of the internal auditor, the effectiveness of internal controls, review of operational procedures by internal control officer and usage of external auditor), results of the descriptive and inferential statistics shoes low adoption of auditing practices by the MSMEs.

More so, on the cost and management accounting practices and sustainability of MSMEs (the constructs were: preparation of cash budget, cost analysis, product/segment profitability analysis, preparation of forecast, and adoption of capital budgeting techniques to appraise projects), the findings revealed weak adoption of these practices as the constructs recorded an average score of below $50 \%$ except for cash budgeting which recorded $65.6 \%$ average score. This was further confirmed by the results of the regression analysis which shows an adjusted coefficient of determination of $1.3 \%$ value points.

In analyzing the joint effects of all the variables, the result reveals that the variables exhibit a significant effect on sustainability accounting for about $40.2 \%$ variation. The implication is that if well understood and applied, financial reporting practices can minimize the mortality rate of MSMEs which has been the common feature of these groups of enterprises in developing countries such as Nigeria.

\section{SumMary, CONCluSion AND RECOMMENDATIONS \\ Summary of Findings}

This study centered on Financial Reporting Practices (FRP) and sustainability of Micro, Small and Medium Scale Enterprises (MSMEs) in Akwa Ibom State. The main objective of the study was to ascertain the linkage between financial reporting practices and the sustainability of MSMEs. From the specific objectives, the following null hypotheses were formulated:

(i) Financial accounting practices do not affect the sustainability of MSMEs.

(ii) Auditing practices have no significant relationship with the sustainability of MSMEs.

(iii. Cost and Management accounting practices have no significant relationship with the sustainability of MSMEs.

(iv) The joint effect of financial accounting, auditing, and cost/management practices does not significantly affect the sustainability of MSMEs. The formulated null hypotheses were analyzed using multiple regressions.

followings:

Results from the analysis showed the

\section{CONCLUSION}

Based on the major finding in this study, there is a relationship between financial reporting practices and the sustainability of MSMEs in Akwa Ibom State. However, there is a positive and significant relationship between financial accounting practices and sustainability of MSMEs; a low and non-significant relationship between auditing financial practices and sustainability of MSMEs; and a low and non-significant relationship between cost and management accounting practices and sustainability of MSMEs when tested independently. This implies that an improvement in 
auditing accounting practices would enhance the sustainability of MSMEs in the studied firms. Equally, the analysis of the joint effects of the independent variables and the dependent variable produced mixed results. While financial accounting practices have a positive and significant effect on the sustainability of MSMEs, auditing, and cost/management accounting practices produced negative and low but non-significant effects on the sustainability of MSMEs respectively.

\section{Business Implications of Findings}

This study examined the relationship between financial reporting practices and the sustainability of MSMEs. Among other things, results from the analysis showed that financial accounting practices have a positive and significant relationship while auditing and cost/management accounting practices showed low and non-significant relationships respectively. This implies that for all financial reporting practices studied, an improvement in the adoption and usage of financial accounting practices would enhance the sustainability of the studied MSMEs. Altogether, this strengthened the fact that financial reporting practices are a crucial aspect required in carrying out businesses among MSMEs. In a large organization, effective practice of financial accounting practices helps to provide the required financial details that the owners and shareholders of the business need to evaluate, monitor as well as make informed decisions regarding the business. The need and practice of financial reporting practices among MSMEs have equally increased recently as firms have leveraged their accounting practices with various information technologies to improve their business processes, procedures as well as enhance their competitive advantage and business sustainability.

\section{Contribution to Knowledge}

Past studies on the relationship between financial reporting practices and the sustainability of MSMEs have gradually increased over time in accounting literature. Progressively, extant accounting literature in this direction has merely examined the relationship between financial accounting practices on the sustainability of MSMEs without recourse to the specific effects financial accounting practices would exert on the sustainability of MSMEs. Such studies of such nature make it almost impossible to generalize research findings thereby making it difficult to strengthen the outcome of a given research outcome, especially among firms in a given industry. Given these structural differences, this study sought to examine the relationship between financial accounting practices and the sustainability of MSMEs in Akwa Ibom State. This would contribute to the already existing global literature and breach the gap between national outlook and global posture as it relates to this study.

\section{RECOMMENDATIONS}

Based on major findings from this study, the following recommendations were made:

i. Since financial accounting practices significantly enhance the sustainability of the studied MSMEs, more attention should be paid to improving the awareness and knowledge of MSMEs owners on the adoption and usage of financial accounting practices;

ii. Most of the MSMEs owners and stakeholders who do not engage in auditing practices conform to the overwhelming number of business owners who believe that auditing practices are not required in MSMEs. Thus, owners of the studied MSMEs should regularly engage in training, seminars, workshops as well as hire auditing experts as these would help in effective supervision of their business; they should also employ and crate internal audit department in the organizations as a check on daily operations and

iii. The studied MSMEs should review their cost and management accounting practices with a view of adopting contemporary cost and management accounting practices that would help significantly in the general sustainability of MSMEs' performance. This will help them in product/service pricing, budgeting, profitability, and cost analysis, among other performance management techniques.

\section{Limitations of the Study}

The study centers on all categories of micro, small and medium, enterprise operating in Akwa Ibom State covering diverse sectors of the economy. MSMEs to be used for the study are those that have survived five (5) years and above. Also, financial reporting practices to be employed for the study are those that fall within financial accounting (record keeping up to the preparation of final accounts), internal and external auditing issues, and basic cost/management accounting techniques that MSMEs can adopt in their operations. Other financial reporting issues such as the adoption of International Financial Reporting Standards (IFRSs) by SMEs, cash flow analysis, financial management practices are outside the scope of this study as well as entities classified within the framework of large-scale businesses.

\section{REFERENCES}

1. Moore, W. C. and Petty, J. W. (2013). Managing Small Businesses account. Asian Journal of Business and Management Sciences, 1(9): 128-147.

2. Zotorvie, J. S. T. (2017). A Study of Financial Accounting Practices of Small and Medium scale Enterprises (SMEs) in HO Municipality, Ghana. International Journal of Academic Research in Business and Social Sciences, 7(7):29-39. 
3. Gunter, M. C. (2005). The effects of size, growth and capital on performance of MSMEs. Journal of Finance, 24:517-529.

4. Okafor, U. I., \& Daferighe, E. E. (2019). Accounting Practices and Performance of Small and Medium Scale Enterprises (SMEs) in Akwa Ibom State, Nigeria. IOSR Journal of Business and Management (IOSR-JBM,), 21(8): 1-9.

5. Frimpong, C. Y. (2013). SMEs as an engine of Social and economic development in Africa. Accessed from https://www.modevaghana.com/news/47825/1/sme s.

6. Schwerk, C. R., \& Schrader, C. (1993). Effects of formal strategic planning on financial performance in small firms: A meat-analysis. Entrepreneurship, the theory and practice, $17(3)$ : 14-22.

7. Howard, P. (2009). Good recording important for successful business: Angelo State University - working paper 15 on Developing MSMEs, 215p.

8. Madurapperama, M., Thilakerathn, P. and Manawadu, I. (2016). Accounting Record Keeping Practices in Small and Medium sized Enterprises (SMEs) in Sri Lanka. Journal of Finance and Accounting, 4(4):188-193

9. Larson, C. M., \& Clute, R. C. (1997). The failure syndrome. American Journal of Small Business: 9-12.

10. Yahaya, K., Osemene, O., \& Salman, R. (2011). Improving the accounting practices adopted by owners of small and medium-scale enterprises in Kwara State - Nigeria. British Journal of Economic, Finance and Management Science, 2(2):7 1-81.

11. Turyahebwa, A., Sunday, A., \& Sekajuge, D. (2013). Financial Management Practices and Business Performance of Small and Medium Enterprises in Western Uganda. African Journal of Business Management, 7(3 8):3875-3885.

12. Boachie-Mensah, N., \& Marfo-Yiadom, E. (2005). Entrepreneurship and Small Business Management. Ghana University Press, Accra, 290p.

13. Anlcrah, E., Mensah, C. C., \& Ofori-Atta, K. (2015). The Relevance of Accounting Information in the Management of Small Enterprises in Ghana. European Journal of Business and Management, 7(8): 141-164.

14. Central Bank of Nigeria (CBN). (2010). Guidelines for the Operations of the Micro Credit Fund. Development Financial Department, CBN, Abuja, pp. 1-3.

15. Mintah, E. K., Nayfordadjei, M., \& Anokye, O. A. (2004). Assessing Financial Reporting Practice among small scale enterprise in Kumasi metropolitan Assembly. European Journal of Business and Social Sciences, 2(10):81-96.

16. Eloho, D. K. (2016). Small and Medium Scale enterprise in Nigeria: Their characteristics, problems and sources of finance, Nairobi: African Economic Research Consortium, pp. 1-28.

17. Zindiye, S. (2008). An Empirical Investigation into the factors affecting the performance of small and medium enterprises in the manufacturing industry of Harare. Unpublished Master's Dissertation, University of Fort-Harare, 118p.

18. Maseko, D., \& Manyani, O. (2011). Accounting Practices of SMEs in Zimbabale: An Investigative study of Record Keeping for Performance Measurement. Journal of Accounting and Taxation, 3(8):171-181.

19. Black, S. (2005). Financial Characteristics of Small Companies in the UK. Journal of Operations Management, 1(6):42-58.

20. Sanni, O. O. (2019). Small-Scale Industry: Problems of establishing Business Enterprise in Nigeria (Case study of Alahteef Nigeria Ltd), NIB Thesis, University of Applied Sciences, Vasa Vrkeshogskola, 142p. Available at http://www.applied sciencesuniversity.doc/thesis/

21. Maseko, N. (2011). Accounting practices of SMEs in Zimbabwe: An Investigative study of record keeping for performance measurement. Journal of Accounting and Taxation, 3(8):171-181.

22. Udofot, P. O., \& Udoidem, J. O. (2014). Issues in the management of the supply- side financing of micro, small and medium enterprises (MSMEs) in Nigeria. British Journal of Economic, Management and Trade, 4(8):1203-1213.

23. Wiltshire Committee (1973). Inquiry on Small Firm. Available at http://books.google.com.ng/books? Retrieved 12/01/2020.

24. Nguyen, K. M. (2001). Financial Management and Profitability of Small and Medium Enterprises. DBA Thesis, Lismore, NSW: Southern Cross University, 13lp.

25. Ekpo, N. B. (2014). Financial Management Practices and growth performance of Micro, small and medium enterprises in Akwa Ibom State, Ph.D thesis, University of Uyo, $128 \mathrm{p}$.

26. Ojo, A. T. (2010). The Nigerian Maladapted Financial System: Performing Tasks and Development Dilemma. Lagos Nigeria: The CIBN Press Limited, 380p.

27. Fatoki, O. O. (2011). The Impact of Human, Social and Financial Capital on the performance of small and medium-sized Enterprises (SME5) in South Africa. Journal of Social Sciences, 29(3): 193-204.

28. Malhotra, K. (2006). Small enterprise or the informal sector? Small Enterprise development. $A n$ International Journal, 6:49-52.

29. Etim, E. O. (2015). Relevance of accounting records in the development and sustainability of small and medium sized businesses. African Journal of Entrepreneurship, 3(2): 14-23.

30. Akinruwa, A. I., Awolusi, D., \& Ibojo, K. (2013). The determinants of small and medium-sized 
enterprises performance in Nigeria. Advances in Economics and Business, 3;184-189

31. Garrigos-Simon, K. Marques, D., \& Naragajavana, R. (2015). Competitive strategies and performance of Spanish small and medium enterprises. International Journal of Contemporary Business and Management, 17(1):22-38

32. Sand, R. A., \& Patel, D. (2006). Management of small businesses in the phase of competition. Journal of Management, Marketing and Decision Science, 27(1):71-93.

33. Asogwa, I. E. (2017). Sustainability Reporting and Financial Performance: A Conceptual Landscape. Research Journal of Finance and Accounting, 8(10): 124-131.

34. Gray, K. R., Owen, B., \& Maunders, D. (1987). Factors Constraining the Growth and Survival of Small-Scale Business: A Developing Country's Analysis. Journal of American Academy of Business 8(2): 167-178.

35. Hall, A. R. (2019). Accounting structure for SMEs performance assessment un the enlarged European countries. Journal of Business, management and policy 42(2):1143-1158

36. Alasadi, A., \& Abdelrahim, K. (2007). Factors determine small business (SBS) success in Kuwait. Asian Economic and Financial Review, 7(9):929942

37. Richard, A. R., Abu, EL.Haj, Joyce, D., \& Atalay, J. (2008). Small business accounting system in Malaysia. Asia Journal of Accounting and Finance, 18(1):11-28

38. Lumpkin, G. T., \& Dess, G. G. (1996). Classifying the entrepreneurial orientation construct and linking it to performance. The Academy of Management Review, 21(1): 135-172

39. Kaplan, R. S., \& Norton, D. P (1996). The balanced scorecard-measure that drive performance. California management review, 39(1):1-25

40. Ateino, O. P (2009). An analysis of the strength and limitation of qualitative and quantitative research paradigms. Journal of Research in Education, 13:13-18

41. Ngerebo, T. A (2017). Analysis of factors affecting survival of small businesses in Rivers state, Nigeria. Management and Administrative Sciences Review, 6(4): 159-170

42. Edminister, S. (2010). Managing local resources by small and medium scale enterprises in Nigeria. Asian Journal of Economics and Management

43. Thomas, D. and Evans, D. (1987). The relationship between firm growth, size and age. Estimates for 100 manufacturing industries. Journal of Industrial Economics, 35(4):567-581

44. Davidson, W. and Dutia, D. (1987). Barriers to liquidity of small industrial enterprises. Journal of Finance and Management Sciences, 3:1073-1079
45. Lev, J. A (1983). Some economic determinants of time-series properties of earnings. Journal of Accounting and Economics, 5:31-48

46. Burns, J. M (1985). Transformational leadership. Journal of Economics and Management Research, 11(2):429-433

47. Storey, A., Leighton, P., \& Adesua, A. (1987). Factors influencing small and medium enterprises (SMEs): an explanatory study of owner/manager and firm characteristics. Journal of Banks and Banks System, 3(3):4-13

48. Udubah, S. I. (2010) Unemployment and economic growth in Nigeria in the $21^{\text {st }}$ century; SMEs in the rescue. Journal of Economics Studies, 07(02):113124

49. Hudson, M. S., \& Bourne, M. (2011). Identification of factors influencing the performance of small medium enterprises (SMEs). Journal of Social and Behavioural Sciences, 115:415-423

50. Delmar, P. D., Achtenlagen, L. and Naldi, L. (2018). Research on small firm growth: A Review. Journal of International Business research, 41(3):1141-1163.

51. Fitzsimmons, J. R., Steffens, P. and Douglas, E. (2005). Growth and profitability in small and medium sized Australian firms. SSRN Electronic Journal, 101(2):126-137

52. Kimberley, D. A. (1976). Keeping accurate business records for optimal decisions. Journal of small Business Management, 4(2): 241-263

53. Penrose, E. (1959). Contributions to the resourcebased view of strategic management. Journal of Management Studies, 41(1):183-191

54. Cooper, A. C and Artz. K.W (1995). Determinants of satisfaction for entrepreneurs. New England Journal of Entrepreneurship, 7(2):1-13

55. Padachi, K. (2012). Factors affecting the adoption of formal accounting systems by SMEs. Business and economics Journal, 67:1-20

56. Pavtar, A. A. (2017). Accounting Practices of SMEs: Challenges and Effects: A survey of SMEs in Makurdi Metropolis — Benue State, Nigeria. World Journal of Finance and Investment Research, 2(1):16-29.

57. Kalu, U. (2016). Financial reporting and analysis, Value Consults Publishers, Lagos, 342p.

58. Igben, R. 0. (2016). Financial Accounting Made Simple, 5th ed. Fully IRRS - Compliant, ROT Publishers, Lagos, 427.

59. Uzuh, J. (2010). Fundamental Principles of Auditing, Assurance Services and Investigations. Lagos, Supreme Konsults Publishers.

60. Babatunde, F. (2016). Auditing and Assurance Service Companion. K-R Publishers, LagosNigeria; 345

61. Adeniyi, A. A. (2018). Simplified Management Accounting. Value Analysis Consult - Publishers, Lagos-Nigeria, 482.

62. Venkatarman, C. J. (1984). Effects of Bookkeeping on Growth of Small and Medium Business 
Enterprises in Kenya. International Journal of Science and Research, 3:432-437.

63. Obara, L. C., \& Ukpai, N. A. (2011). Cost accounting practices in the informal sector of Nigeria: A survey of Eastern Business Zone. African Training and Research Centre in Administration for Development, 1(2):63-68.

64. Abusomwan, K., \& Oghogho, R. (2016). The reliance of accounting records in small scale businesses: The Nigerian Experience. International Journal of Academic Research in Business and Social Science, 4(12):69-82.

65. Loikkanen, L. (2018). Accounting Practices of Individual Entrepreneur in the context of accounting. Journal of Information System, 4(1): 146-161.

66. Muteti, N. M., Namusonge, M. and Nzomo, D. N. (2018). Accounting Practices and Enterprises Development in Selected Small Enterprises in Makueni Country. African Journal of Business Management and accounting, 5:3781-3793.

67. Adjei, D. (2012). Micro, Small and Medium Scale Enterprises in Ghana: Challenges and Prospects. A Case study of Sekandi-Takoradi, Metropolis, Journal of Accounting and Taxation, 3(8): 17-181

68. Rathnasiri, U. A. (2014). Financial Reporting Practice of Small and Medium Enterprises (SMEs) in Sri Lanka. South East Asia Journal of Contemporary Business, Economic, and Law, $4(1): 15-23$.
69. Boame, I., Kudadze, S. and Sulemana, I. (2014). Adoption of Accounting Practices and its effects on SMEs: Financial Perspective of Sachet Water Producers in Northern Region of Ghana. Research Journal of Finance and Accounting, 5(17):166-180.

70. Ntim, A. L., Evans, O., \& Anthony, F. (2014). Accounting Practices and control Systems of small and medium size entities: A case study of Technical Municipality, Ghana. Journal of Finance and Accounting, 2(3):30-40

71. Hamza, K., Mutala, Z., \& Stephen, K. (2015). An Assessment of the Inventory Management Practice of Small and Medium Enterprises (SMEs) in the Northern Region of Ghana. European Journal of Business and Management, 7(20):28-39

72. SMEDAN (2008). Small and Medium Enterprise Performance in Nigeria. A Report presented at African Entrepreneurship Seminar organized in collaboration with the scientific committee on Entrepreneurship, UK: University of Essex, 53p.

73. Mbroh, J., \& Attom, E. (2011). Accounting and Controls Systems Practiced by Small and micro enterprise owners within the Cape Coast Metropolitan areas of Ghana. Asian Journal of Business and management sciences, 1(9):28-47.

74. Okoli, B. (2011). Evaluation of accounting systems used by small scale enterprises in Nigeria. The case of Enugu South East Nigeria. Asian Journal of Business Management, 3(4):235-240.

\section{APPENDIX \\ A - Bio Data}

Please tick $\bigvee$ appropriate

1. What is your gender? Male $\square$ Female

2. How long have you worked in the organization? $1-5$ years $\square$ 6-10 years $\square$ 11- above years

3. What position do you hold in the organization? Administration officer $\square$ financial controller $\square$ Executive manager

$<$

B Commonly Adopted Financial Reporting Practices

Please tick $\square$ the practice often applied in your reporting of financial performance?

1. Financial accounting reports

2. Management accounting reports

3. Cost accounting reports

4. Auditing accounting reports

1. Preparation of statement of profit/loss

\section{Financial Accounting Practice}

2. Preparation of statement of financial position (balances sheet)

3. Preparation of cashbook and bank reconciliation statement.

4. Purchase and sales day books

1. Annual budget preparation/forecast

\section{Cost/Management Accounting Practices}

2. Break-even/cost volume profit analysis adoption

3. Sales analysis $\square$

4. Product/profitability analysis 
APPENDIX I

SAMPLE OF THE QUESTIONNAIRE

\begin{tabular}{|c|c|c|c|c|c|c|}
\hline $\mathbf{S} / \mathbf{N}$ & Independent variables & $\mathbf{0}$ & 1 & 2 & 3 & 4 \\
\hline & I. Financial Accounting Practices $\left(\mathbf{X}_{1}\right)$ & NE & $\mathbf{L E}$ & ME & LGE & VLE \\
\hline 1 & $\begin{array}{l}\text { To what extent has your company adopted cash book } \\
\text { keeping practices }\end{array}$ & & & & & \\
\hline 2 & $\begin{array}{l}\text { To what extent do you adopt banking transactions in } \\
\text { your operations }\end{array}$ & & & & & \\
\hline 3 & $\begin{array}{l}\text { To what extent do you carryout bank reconciliation } \\
\text { statement? }\end{array}$ & & & & & \\
\hline 4 & To what extent do you prepare financial statements? & & & & & \\
\hline \multirow[t]{2}{*}{5} & $\begin{array}{l}\text { To what extent do you maintain sales and purchases } \\
\text { records? }\end{array}$ & & & & & \\
\hline & II. Auditing practices $\left(\mathrm{X}^{2}\right)$ & NE & $\mathbf{L E}$ & ME & LGE & VLE \\
\hline 6 & $\begin{array}{l}\text { To what extent do you relied on internal audit services } \\
\text { in your operation? }\end{array}$ & & & & & \\
\hline 7 & $\begin{array}{l}\text { To what extent is the internal auditor independent (if } \\
\text { any)? }\end{array}$ & & & & & \\
\hline 8 & $\begin{array}{l}\text { To what extent is the effectiveness of your } \\
\text { organization's internal controls? }\end{array}$ & & & & & \\
\hline 9 & To what extent does the internal control officer review & & & & & \\
\hline 10 & $\begin{array}{l}\text { To what extent do you use the services of external } \\
\text { auditor to review your reports? }\end{array}$ & & & & & \\
\hline
\end{tabular}

\begin{tabular}{|l|l|l|l|l|l|l|}
\hline & III. Cost management Accounting practices $\mathbf{X}^{3}$ ) & NE & LE & ME & LGE & VLE \\
\hline 11 & $\begin{array}{l}\text { To what extent do your organization prepare cash } \\
\text { budget }\end{array}$ & & & & & \\
\hline 12 & $\begin{array}{l}\text { To what extent do your organization carryout cost } \\
\text { analysis? }\end{array}$ & & & & & \\
\hline 13 & $\begin{array}{l}\text { To what extent do your organization product/segment } \\
\text { profitability analysis? }\end{array}$ & & & & & \\
\hline 14 & $\begin{array}{l}\text { To what extent do your organization prepare } \\
\text { operational forecast? }\end{array}$ & & & & & \\
\hline 15 & $\begin{array}{l}\text { To what extent do your organization adopt budgeting } \\
\text { techniques to appraise capital projects? }\end{array}$ & & & & & \\
\hline
\end{tabular}

